\title{
THE ASSOCIATION ERYSIMO - TRIFOLIETUM MICEV. 1977 IN BULGARIA AND SOME REMARKS ON ITS MEDITERRANEAN CHARACTER
}

\author{
Desislava SOPOTLIEVA* \& Iva APOSTOLOVA*
}

\begin{abstract}
We endeavor to enlarge the knowledge about Bulgarian vegetation diversity. Data on seminatural grasslands containing 344 relevés, collected in Southeast Bulgaria were analyzed by the combine method, using TWINSPAN and the Cocktail method. The Erysimo diffusii-Trifolietum angustifolii association and the alliance Trifolion cherleri were established for the first time in Bulgaria. So far the presence of this association was known for Macedonia. The aims of our study are to present more data about the Erysimo-Trifolietum in Bulgaria and to make some comments about its affiliation to Helianthemetea guttati. The association is characterized ecologically and floristically. Analysis of the floristic elements shows that the most numerous are sub-Mediterranean species. Analysis of the life forms shows that these communities are hemicryptophyte-therophytic. A review of syntaxonomical systems and association assignment to higher syntaxa were made. According to current European vegetation surveys the association should be related to class Helianthemetea guttati. Our results reveal an intermediate character of the studied vegetation - closed dry grasslands, with distinct presence of Festuco-Brometea species with a high percent of therophytes and Mediterranean floristic elements related to Helianthemetea guttati as well.

Key words: dry grasslands, syntaxonomy, Helianthemetea guttati.

Izvleček

Članek je prispevek k poznavanju raznovrstnosti vegetacije Bolgarije. Podatke, ki obsegajo 344 popisov, narejenih v jugovzhodni Bolgariji, smo analizirali s kombinacijo metod TWINSPAN in Cocktail. Asociacija Erysimo diffusii-Trifolietum angustifolii in zveza Trifolion cherleri sta prvič omenjeni v vegetaciji Bolgarije. Do sedaj je bila prisotnost te asociacije poznana le v Makedoniji. Namen raziskave je predstaviti dodatne podatke o asociaciji Erysimo-Trifolietum v Bolgariji in podati nekaj komentarjev o njeni uvrstitvi v razred Helianthemetea guttati. Asociacija je označena ekološko in floristično. Analiza flornih elementov je pokazala, da so submediteranske vrste najštevilnejše. Analiza življenjskih oblik pa, da je to hemikriptofitsko-terofitska združba. Opravljen je pregled sinataksonomskega sistema in uvrstitev v višje sintaksone. Po trenutnem pregledu evropske vegetacije jo uvrščamo v razred Helianthemetea guttati. Naši rezultati pa razkrivajo vmesni značaj obravnavane vegetacije - sorodnost s suhimi travniki s prisotnostjo vrst Festuco-Brometea in visokim odstotkom terofitov in z razredom Helianthemetea guttati, ki ga označujejo mediteranski elementi.
\end{abstract}

Ključne besede: suhi travniki, sintaksonomija, Helianthemetea guttati.

\section{INTRODUCTION}

The Bulgarian phytogeographic position predetermines conditions for the presence of Central European as well as Mediterranean floristic elements, i.e. respective vegetation types (cf. Bohn et al. 2003). Unlike the vegetation of most European countries, Bulgarian vegetation is still poorly studied following the floristic criteria. Up to the recent several years in the phytosociological investigations the dominance approach was applied (Apostolova \& Slavova 1997). This results in questions so far unanswered, as for example "what is the diversity of alliances and associations within the class Festuco-Brometea in the country", or "does Helianthemetea guttati reach the country territory"? During the Bulgarian grassland inventory (Meshinev et al. 2005) Mediterranean floristic elements in the her-

\footnotetext{
* Institute of Botany, Bulgarian Academy of Sciences, Acad. Georgi Bonchev St., bl. 23, 1113 Sofia, Bulgaria
} 
baceous vegetation of southern Bulgarian regions, were distinguished, and the Thero-Brachypodietea class was reported for the country.

The Erysimo-Trifolietum association, which is the subject of the current study, is described by Micevski (1977). This association belongs to the Trifolion cherleri Micev. 1970 alliance. It is widely distributed in the central north and northeastern parts of the Republic of Macedonia (Micevski 1977).

The presence of similar communities in the territories surrounding Bulgaria poses a question about the existence of the same vegetation in the country. The aims of this study are to present more data about the Erysimo-Trifolietum association and to make some comments about its affiliation to Helianthemetea guttati.

\section{MATERIAL AND METHODS}

The study region is situated, between $42-43^{\circ} \mathrm{N}$ and $26-27^{\circ} \mathrm{E}$, in Southeast Bulgaria (Fig. 1). It is assigned to the Straldzha-Aitos phytogeographic region (Bondev 2002). The region is characterized by mild climate with mean annual temperatures $12.2^{\circ} \mathrm{C}$ for the Aitos and Yambol, $12.4^{\circ} \mathrm{C}$ for Sliven and mean annual precipitation $490.6 \mathrm{~mm}$ for Aitos, $567 \mathrm{~mm}$ for Sliven and $535.9 \mathrm{~mm}$ for Yambol (unpublished data provided by Bulgarian National Institute of Meteorology and Hydrology, Bulgarian Academy of Sciences). Field investigations were carried out throughout the years 2004 and 2005, according to the methods of the Braun-Blanquet School (BraunBlanquet 1964, Westhoff \& van der Maarel 1980). The data about natural and semi-natural grassland vegetation were sampled. The total number of collected relevés was 344 . The standard relevé area was $16 \mathrm{~m}^{2}$ (Chytrý \& Otýpková 2003). The cover of vascular plant and bryophyte was estimated using the nine-grade Braun-Blanquet scale (Barkman et al. 1964). Altitude and coordinates were measured by GPS Garmin Etrex Summit (WGS 84 system) with altimeter calibrated by current atmospheric pressure. Slope, soil depth and soil moisture were estimated.

The nomenclature of vascular plants follows Kozhuharov (1992) and the bryophyte nomenclature follows Natcheva \& Ganeva (2005). The floristic elements were established according to Assyov \& Petrova (2006) for the vascular plants and according to Ganeva \& Düll (1999) for the bryophytes. Life forms are estimated using the data about biological types in Kozhuharov (1992).

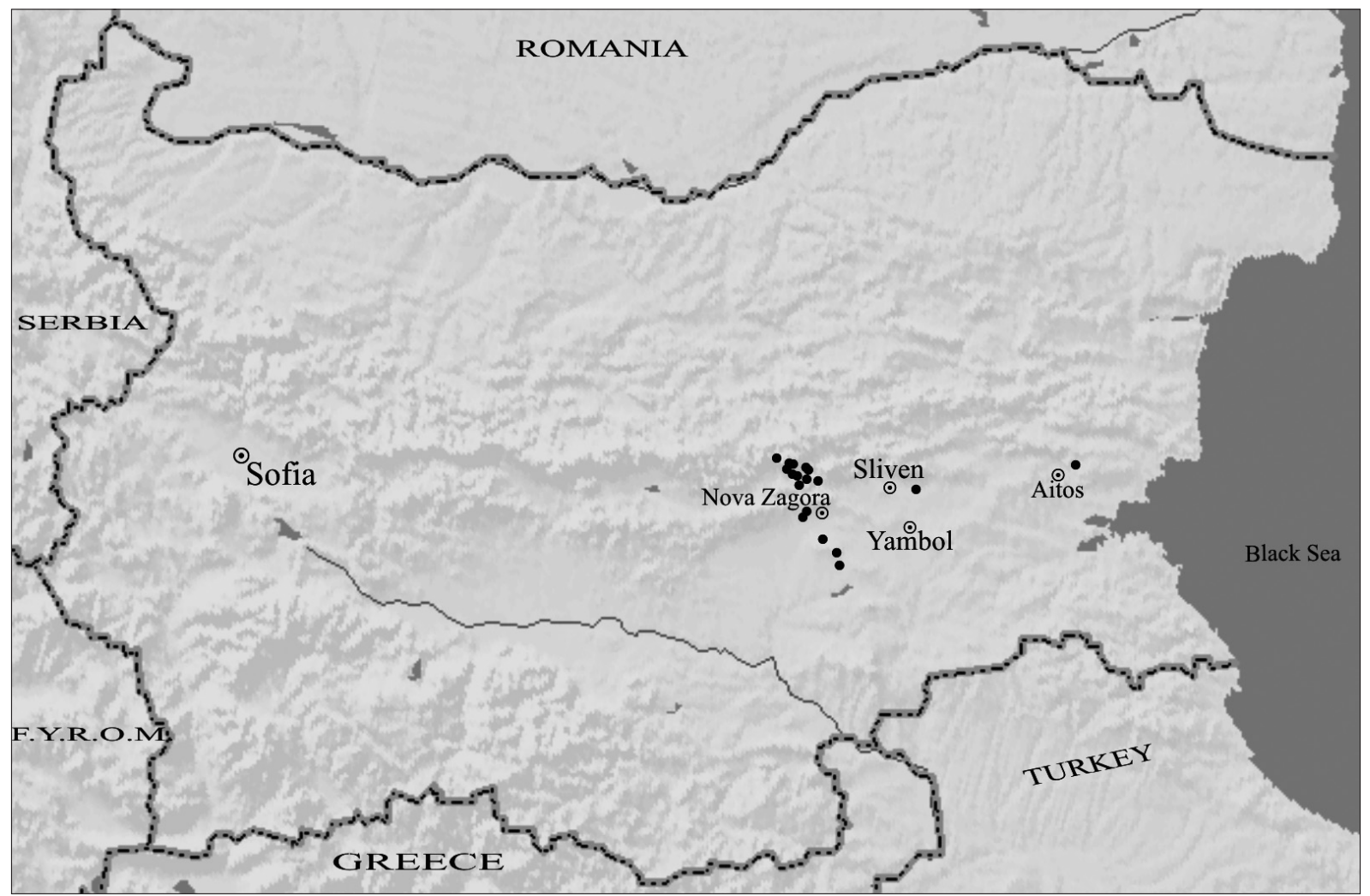

Figure 1: Points of the studied localities. / Slika 1: Lokacije proučevanih sestojev. 
The data set was entered and stored in the TURBOVEG database (Hennekens \& Schaminée 2001) and then exported into JUICE software (Tichý 2002). A polythetic, divisive classification that uses two-way indicator species analysis (TWINSPAN, Hill 1979) was applied. The resulting vegetation types roughly corresponded with the phytosociological alliances. These vegetation types were then checked by the statistical tendency of species to have a joint occurrence in vegetation by the Cocktail method (Bruelheide 1995), using the phi-coefficient (Chytrý et al. 2002). The Cocktail method and phi-coefficient were used to find the diagnostic species. Based on results of the Cocktail method, several relevés were manually moved within the groups for better representation of the diagnostic species groups. All undetermined groups were removed from the subsequent analysis. As a result the amount of 175 phytosociological relevés was classified into six alliances, and in the synoptic tables species were ranked according to their fidelity value for individual clusters (Sopotlieva in press). Fidelity was calculated by the phi-coefficient of association, applied to the classified data set with equalised sizes of clusters according to Tichý \& Chytrý (2006). Within the alliances, the associations were recognized after referring to the appropriate literature.

Soil samples were collected in the studied area at $5-10 \mathrm{~cm}$ depth and basic soil properties $(\mathrm{pH}$, electrical conductivity, humus content, concentration of $\mathrm{CaCO}_{3}$ ) were analysed. The samples were air-dried. The pre-treatment of samples for chemical analyses follows ISO 11464:1994 (E). Electrical conductivity (EC) and $\mathrm{pH}$ were measured in water solution using a 1:5 soil:water ratio and using $\mathrm{pH}-$ meter Jenway3310 (ISO 10390:1994 (E)). $\mathrm{CaCO}_{3}$ concentration was measured in 1:10 water solution using Photometer PC 22, the results are presented as $\mathrm{mg} / \mathrm{l}$. Humus was determined according to the modified Turin method (Kononova 1966). All the analyses were performed in the Analytical Laboratory, Department of Phytocoenology and Ecology in the Institute of Botany, Bulgarian Academy of Sciences.

\section{RESULTS AND DISCUSSION}

Detailed sampling of grassland diversity in the Straldzha - Aitos phytogeographic region revealed the presence of Trifolion cherleri alliance. All relevés confined to this cluster were homogenous and obviously belong to one association. So far several different associations are described within this alliance (Micevski 1972, 1973, 1977, Micevski \& Matevski 1984, Matevski \& Kostadinovski 1998). Based on the diagnostic species group, in the studied region appears the association Erysimo-Trifolietum Micev. 1977. It is documented by 18 phytosociological relevés and is reported for the first time for Bulgaria.

\section{Characteristics of the association in Bulgaria}

Our investigation shows that its communities predominantly cover terrains with sunny expositions and slopes up to $15^{\circ}$. Soils are shallow or with medium depth and dry. So, the terrains are similar to those in Macedonia, as compared with the data published by Micevski (1977). The altitude ranges between 200 and $350 \mathrm{~m}$, while in Macedonia it reaches up to $900 \mathrm{~m}$ above sea level. From the mean values of the examined soil parameters it appears that in Bulgaria the association Erysimo-Trifolietum grows on slightly acidic to neutral soils (average $\mathrm{pH}$ 6.22) with average electrical conductivity $37.3 \mu \mathrm{S} . \mathrm{cm}^{-1}$. The organic matter varies, but most often it is between $2-3 \%$, which corresponds with the considerably low nutritient availability. $\mathrm{CaCO}_{3}$ has an average content of $51.3 \mathrm{mg} . \mathrm{l}^{-1}$ (Table 2).

The floristic composition of the association is shown in Table 1. The plants diversity includes 161 taxa. The average number of species per relevé is 31.4. As compared with the relevés published by Micevski (1977) species diversity in Macedonia is higher.

The association character species, in our data (Trifolium angustifolium, Vulpia myurus, Erysimum diffusum, Trifolium striatum ) (Table1) includes species with highest constancy among the character species for the association, as described by Micevski (1977). In Bulgaria these species grow in dry grasslands communities in lowlands and hilly regions (Kozhuharov 1992), and thus they correspond well to the ecological conditions, occupied by the communities of the association.

The Trifolion cherleri alliance is represented by 11 species (Table 1 ). The relatively low constancy (II) of most of the species, which belong to alliance Trifolion cherleri, including the clover Trifolium cherleri, could be explained by the fact that our data were sampled from the region situated further north than the still known areal of the association. Micevski (1977) mentions that northward the com- 
munities start to lose some diagnostic species. According to him, among the other Trifolion cherleri associations (Tunico-Trisetum myrianthi Micev. 1972, Helianthemo-Euphorbietum thessalae Micev. 1973, Diantho-Cistetum incani Micevski \& Matevski 1984, Biserrulo-Scleranthetum dichotomae Matevski \& Kostadinovski 1998), Erysimo-Trifolietum association has the most continental character. The author states also that this is obvious by the decreasing number, abundance and constancy of the Mediterranean species. The clover Trifolium cherleri, the most character species to the alliance, has a V degree of constancy in the associations Tunico-Trisetum myrianthi and Helianthemo-Euphorbietum thessalae, but in the Erysimo-Trifolietum it has different constancy in the different areas or does not occur in all the localities of association in Macedonia.

The analysis of the floristic elements shows that the most numerous are sub-Mediterranean species (28), followed by Euro-Asiatic (25); Euro-Mediterranean and Euro-sub-Mediterranean (24); Mediterranean (16); boreal and sub-boreal (10); Pontic-Mediterranean (9); Pontic and Pontic-Siberian (9); Balkan, Balkan-Dacian, Pannonian-Balkan and Apenninian-Balkan (9). The other types contain 7 or less than 7 species (Table 1). Thus the Mediterranean floristic element (including Mediterranean, sub-Mediterranean, Euro-Mediterranean and Euro-sub-Mediterranean) has a convincing presence in the studied vegetation $(42 \%)$.

Analysis of the types of life forms shows that these communities are hemicryptophyte-therophytic, which also emphasizes their southern affiliation (Table 1). The therophytes are 68 species (42\%). The other approximately one half of the species are hemicriptophytes.

\section{Association assignment to the higher syntaxonomical level}

As proposed by the Braun-Blanquet School, assignment of an association to an alliance (and other higher units) is primarily based on comparison of floristic relationships (Westhoff \& van der Maarel 1980). In this respect, in the original data (Micevski 1977), as well as in our data, the Erysimo-Trifolietum association contains a well-defined group of diagnostic species of alliance Trifolion cherleri and undoubtedly belongs to this alliance.

The Trifolion cherleri alliance is described as "silicicolous therophyte swards of submediterranean character in Macedonia and northern Greece"
(Rodwell et al. 2002). This alliance has not been established in Bulgaria so far. Thus our results prove its enlargement to the North-East.

The position of the alliance Trifolion cherleri in the syntaxonomical system and its relation to higher syntaxa is problematic. When it was described, it was assigned to the order Astragalo-Potentilletalia Micev. 1970 without any decision about the affiliation to a class (Micevski 1970). In the later publications (Micevski 1978; Micevski \& Matevski 1984) the alliance as well as the order was assigned to the class Festuco-Brometea. This class includes grasslands of the temperate and sub-boreal regions (Mucina 1997). Such position presumes a more continental character of the communities of the alliance.

According to the current syntaxonomical vision about European vegetation (Rodwell et al. 2002), Trifolion cherleri belongs to Helianthemetalia guttati Br.-Bl. in Br.-Bl., Molinier \& Wagner 1940 and Helianthemetea guttati (Br.-Bl. in Br.-Bl., Roussine \& Nègre 1952) Rivas Goday \& Rivas-Martínez 1963 em. Rivas-Martínez 1978, which perceives its Mediterranean character.

Analysis of the floristic composition of the Erysimo-Trifolietum association in Straldzha-Aitos phytogeographic region shows that order Astragalo-Potentilletalia is represented by 15 diagnostic species and class Festuco-Brometea is represented by 30 diagnostic species (Table 1), while to the Helianthemetalia guttati belong 7 such species. Class Helianthemetea guttati is represented by 7 species, but four of them occur only in one relevé. These results reveal an intermediate character of studied vegetation closed dry grasslands, with distinct presence of Festuco-Brometea species as well with a high percent of therophytes and Mediterranean floristic elements. In the monograph about the class Festuco-Brometea Royer (1991) comments on the existence of heterogenic groups in Bulgaria, Macedonia, Serbia and probably in Greece, which belong to the class Thero-Brachypodietea with penetrating Festuco-Brometea species. Royer (1991) states that the border between these two classes probably lies in Southern Bulgaria. The studied vegetation type the author assigns to Astragalo-Potentilletalia and Thero-Brachypodietea, i.e. to the vegetation with Mediterranean character.

In some overviews of the Balkan Peninsula vegetation (Horvat et al. 1974; Wendelberger 1965) Trifolion cherleri is not mentioned. Recently, critical revision of Helianthemetalia guttati (Pérez Prieto \& Font 2005) considers only West Mediterranean and does not include this Balkan alliance. 
Even at the broad level of classes, different syntaxonomical schemes were proposed without universal acceptance. During the development of syntaxonomy, within the sandy dry grasslands and related vegetation types of Europe, different vegetation classes were described (Dierschke 1986). Among them, according to Mucina (1997), classes Helianthemetea guttati and Poetea bulbosae are syntaxonomical synonyms of class Thero-Brachypodietea. Rodwell et al. (2002) published the more finely divided scheme and accepted Helianthemetea guttati and Thero-Brachypodietea ramosi as distinct classes within Mediterranean vegetation. This reveals the need of critical revision for dry grassland vegetation in South-East Europe.

\section{CONCLUSIONS}

The Erysimo-Trifolietum association as well as the Trifolion cherleri alliance is distributed in Bulgaria. Despite the fact that these syntaxa are documented only by 18 relevés, the intermediate character of the studied vegetation between the continental and Mediterranean dry grasslands is obvious. This is witnessed by the statements (Royer 1991) that the border between Festuco-Brometea and Helianthemetea guttati lies in Southern Bulgaria.

Further investigations in Bulgaria would be very useful not only to reveal Bulgarian vegetation diversity, but also to help outlining the border between continental and Mediterranean vegetation in the South-East, as well to support the better understanding of European vegetation diversity.

\section{AKNOWLEDGEMENTS}

This work was partly supported by National Grasslands Inventory Project - Bulgaria, 2001-2004 (PINMATRA 2001/020). The authors thank the two anonymous reviewers, whose comments improved the manuscript.

\section{REFERENCES}

Apostolova, I. \& Slavova, L. 1997: Compendium of Bulgarian plant communities. Published during 1891-1995, Sofia, 340 pp.

Assyov, B. \& Petrova, A. (eds). 2006: Conspectus of the Bulgarian Vascular Flora. Distribution maps and floristic elements. Bulgarian Biodiversity Foundation, Sofia, 452 pp.
Barkman, J. J., Doing, H. \& Segal, S. 1964: Kritische Bemerkungen und Vorschläge zur quantitativen Vegetationsanalyse. - Acta Bot. Neerl. 13: 394-419.

Bohn, U., Gollub, G., Hettwer, Ch., Neuhäuslová, Z., Raus, T., Schlüter, H. \& Weber, H. 2003: Karte der Natürlichen Vegetation Europas. Bundesamt für Naturschutz., Bonn, 656 pp.

Bondev, I. 2002: Geobotanic regioning. In: Kopralev, I. (ed.) Geography of Bulgaria, Publ. House ForCom pp. 336-352 (in Bulgarian).

Braun-Blanquet, J. 1964: Pflanzensoziologie. Grundzüge der Vegetationskunde. 3.ed. Springer, Wien, 865 pp.

Bruelheide, H. 1995: Die Grünlandgesellschaften des Harzes und Standortsbedingungen mit einem Beitrag zum Gliederungspringsprinzip auf der Basis von statistisch ermittelten Artengruppen. Diss. Bot. 244: 1-338.

Chytrý, M. \& Otýpková, Z. 2003: Plot sizes used for phytosociological sampling of European vegetation. J. Veg. Sci. 14: 563-570.

Chytrý, M., Tichý, L., Holt, J. \& Botta-Dukát, Z. 2002: Determination of diagnostic species with statistical fidelity measures. Journal of Vegetation Science 13: 79-90.

Dierschke, H. 1986: Entwicklung und heutiger Stand der Syntaxonomie von Silikat-Trockenrasen und verwadten Gesellschaften in Europa. Phytocoenologia 14(3): 399-416.

Ganeva, A. \& Düll, R. 1999: A contribution to the Bulgarian bryoflora. Checklist of the Bulgarian bryophytes. In: Düll, R., Ganeva, A., Martinčič, A. \& Pavletić, Z. Contributions to the bryoflora of former Yugoslavia and Bulgaria. 1 Auflage. IDH-Verlag Bad Münstereifel, pp. 111-199.

Hennekens, S.M. \& Schaminée, J.H.J. 2001: TURBOVEG, a comprehensive data base management system for vegetation data. Journal of Vegetation Science 12: 589-591.

Hill, M.O. 1979: TWINSPAN - a FORTRAN program for arranging multivariate data in an ordered two-way table by classification of individuals and attributes. Section of Ecology and Systematics. Cornell University, Ithaca.

Horvat, I., Glavač, V. \& Ellenberg, H. 1974: Vegetation Südosteuropas. Gustav Fisher Verlag, Stuttgart, $767 \mathrm{pp}$.

ISO 10390. 1994: Soil quality - Determination of $\mathrm{pH}$.

ISO 11464. 1994: Soil quality - Pretreatment of samples for physico-chemical analyses.

Kononova, M. M. 1966: Soil Organic Matter. Its 
Nature, its Role in Soil Formation. ( $\left.2^{\text {nd }} e d.\right)$. Pergamon, N.Y., 544pp.

Kozhuharov, S. (ed.). 1992: Field Guide to the Vascular Plants in Bulgaria. Naouka \& Izkoustvo, Sofia (in Bulgarian).

Matevski, V. \& Kostadinovski, M. 1998: BiserruloScleranthetum dichotomae Matevski \& Kostadinovski ass. nova vo vegetatijata na brdskite pasišta na Republika Makedonija. God. Sborn. Biol. 51: 25-35. (in Macedonian)

Meshinev, T., Apostolova, I., Georgiev, V., Dimitrov, V., Petrova, A. \& Veen, P. 2005: Grasslands of Bulgaria. Final report on the National Grasslands Inventory Project - Bulgaria, 2001-2004. Dragon 2003 Ltd. Publishers, Sofia.

Micevski, K. 1970: Astragalo-Potentilletalia, eine neue Vegetationsordnung der Bergweiden Mazedoniens. Contributions, 2-Section for Natural sciences and Mathematics, Macedonian Academy of Sciences and Arts, 2: 15-23 (in Macedonian).

Micevski, K. 1972: Tunico-Trisetum myrianthi Micev. ass. nov. vo vegetacijata na brdskite pasishta vo Makedonija. Ann. Biol. Fac. Sc. Univ. Kiril i Metodij, 24: 59-65 (in Macedonian).

Micevski, K. 1973: Helianthemo-Euphorbietum thessalae Micev. ass. nov. vo vegetacijata na brdskite pasišta vo Makedonija. Ann. Biol. Fac. Sc. Univ. Kiril i Metodij, 25: 149-155 (in Macedonian).

Micevski, K. 1977: Erysimo-Trifolietum Micev. ass. nov. in der Vegetation Makedoniens. Contributions, 1-Section for Natural sciences and Mathematics, Macedonian Academy of Sciences and Arts, 9: 76-82 (in Macedonian).

Micevski, K. 1978: Typologishe Untersuhungen der Wiesen- und Weiden-Vegetation der gebiete Maleš und Pijanec. Maleš and Pijanec I, MAWV, 9-41 (in Macedonian).

Micevski, K. \& Matevski, V. 1984: Diantho-Cistetum incani Micevski et. Matevski ass. nov. in der Vegetation der Montanen Weideflächen der SR Makedonien. Contributions, 2-Section of Bio- logical and Medical Sciences, Macedonian Academy of Sciences and Arts, 5: 11-16 (in Macedonian).

Mucina, L. 1997: Conspectus of classes of European vegetation. Folia Geobot. Phytotax. 32: 117-172.

Natcheva, R. \& Ganeva, A. 2005: Check-list of the bryophytes of Bulgaria with data on their distribution. II. Musci. Cryptog. Bryol. 26(2): 209232.

Pérez Prieto, D. \& Font, X. 2005: Revisión sintaxonómica a nivel de subalianza del order Helianthemetalia guttati en la Península Ibérica e Islas Baleares. Acta Botanica Malacitana 30: 139156.

Rodwell, J., Schaminée, J., Mucina, L., Pignatti, S., Dring, J. \& Moos, D. 2002: The Diversity of European Vegetation. An overview of phytosociological alliances and their relationships to EUNIS habitats. Wageningen, NL. Report ECLNV nr. 2002/054.

Royer, J.M. 1991: Synthèse eurosibérienne, phytosociologique et phytogéographique de la classe des Festuco-Brometea. Diss. Bot. 178:1-296.

Sopotlieva, D. (in press): The high-rank syntaxa of semi-natural grasslands in Straldzha-Ajtos phytogeographic region. Phytol. Balcan. Vol.13 Suppl.

Tichý, L. 2002: JUICE, software for vegetation classification. Journal of Vegetation Science 13: 451-453.

Tichý, L. \& Chytrý, M. 2006: Statistical determination of diagnostic species for site groups of unequal size. Journal of Vegetation Science 17: 809-818.

Wendelberger, G. 1965: Zur Vegetationsgliederung Südosteuropas. Mitt. d. Naturwiss. Vereins f. d. Steiermark. 95: 245-286.

Westhoff, V. \& van der Maarel, E. 1980: The BraunBlanquet Approach. In: Whittaker, R.H. (ed.): Classification of Plant Communties. Junk, The Hague, Pp. 289-399. 
Table 1: Erysimo-Trifolietum association.

Tabela 1: Asociacija Erysimo-Trifolietum.

\begin{tabular}{|c|c|c|c|c|c|c|c|c|c|c|c|c|c|c|c|c|c|c|c|c|c|}
\hline Number of relevé & & & 1 & 2 & 3 & 4 & 5 & 6 & 7 & 8 & 9 & 10 & 11 & 12 & 13 & 14 & 15 & 16 & 17 & 18 & \\
\hline Altitude $[\mathrm{m}]$ & \multirow{4}{*}{$\frac{\mathscr{a}}{\stackrel{\Xi}{\Xi}}$} & \multirow{4}{*}{ 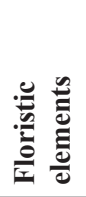 } & $\stackrel{\infty}{m}$ & $\stackrel{\circ}{m}$ & $\stackrel{\circ}{\sim}$ & $\stackrel{\infty}{\stackrel{0}{0}}$ & ঃ্ల & 品 & 워 & $\stackrel{n}{n}$ & $\underset{\sim}{\infty}$ & $\stackrel{\overbrace{}}{\stackrel{\Upsilon}{~}}$ & $\stackrel{2}{\approx}$ & : & $\stackrel{n}{m}$ & $\vec{\infty}$ & $\stackrel{2}{\sim}$ & તָ & $\stackrel{\sim}{\sim}$ & d & \\
\hline Exposition & & & & W & $\mathrm{E}$ & W & $\mathrm{S}$ & SW & $\mathrm{N}$ & $\mathrm{S}$ & NW & & & W & $\mathrm{N}$ & SW & $\mathrm{S}$ & & $\mathrm{S}$ & W & e \\
\hline Cover $[\%]$ & & & 80 & 95 & 90 & 70 & 90 & 95 & 85 & 90 & 100 & 85 & 85 & 75 & 95 & 90 & 85 & 85 & 85 & 85 & 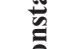 \\
\hline Number of species & & & 26 & 34 & 28 & 30 & 31 & 32 & 27 & 46 & 38 & 19 & 30 & 30 & 28 & 33 & 37 & 34 & 32 & 31 & ن \\
\hline
\end{tabular}

\section{Char. for Association}

Trifolium angustifolium

Vulpia myurus

Erysimum diffusum

Trifolium striatum

Trifolion cherleri

Trifolium arvense

Rumex acetosella

Logfia minima

Petrorhagia prolifera

Trifolium cherleri

Vulpia ciliata

Taeniatherum caput-medusae

Aira elegantissima

Linaria pelisseriana

Silene subconica

Sedum caespitosum

Helianthemetalia guttati

Psilurus incurvus

Trifolium strictum

Filago lutescens

Helianthemetea guttati

Trifolium campestre

Arenaria leptoclados

Medicago minima

Cerastium pumilum

Scleranthus polycarpos

Arenaria serpyllifolia

Acinos arvensis

\section{Festuco-Brometea}

Eryngium campestre

Poa bulbosa

Sanguisorba minor

Thymus striatus

Festuca valesiaca

Chondrilla juncea

Euphorbia cyparissias

Koeleria nitidula

Chrysopogon gryllus

Galium verum
Th med $++++++1 .+.+t_{+}++$. . . . IV

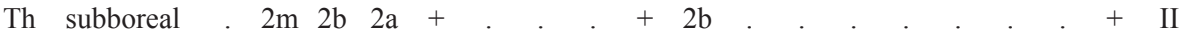

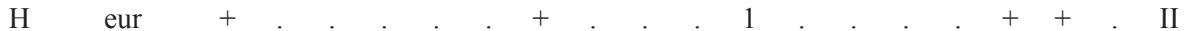

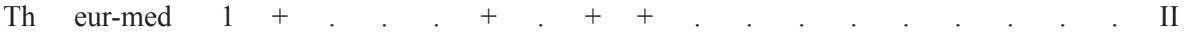

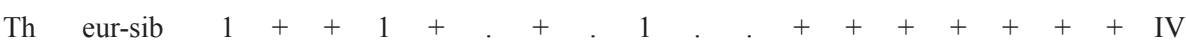

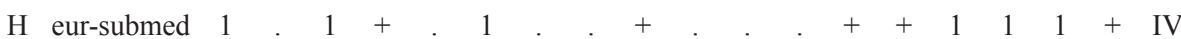

Th eur-sib . + . . . ++ . . . ++ . . + II

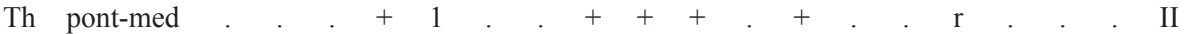

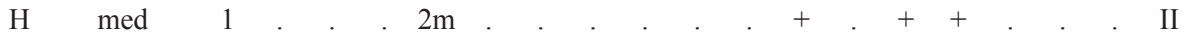

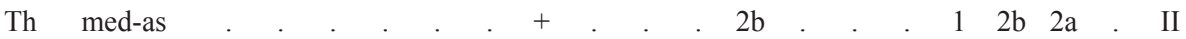

Th eur-as . . ++ ..++ . . . . . . . + . . II

Th med. $2 \mathrm{~m} . . .5 . \quad . \quad . \quad 2 \mathrm{a}++. .+$ II

Th med . . . . . . . . . + . . + + II

Th submed

$\mathrm{H} \quad$ med

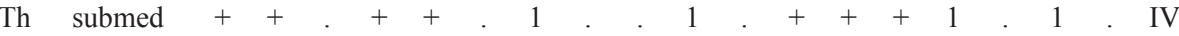

Th eur-sib

Th boreal

Th eur-med $1+++++1++++2 \mathrm{t}+2 \mathrm{a}+\mathrm{V}$

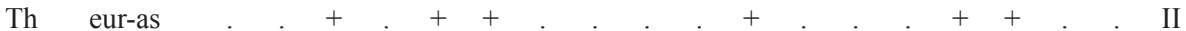

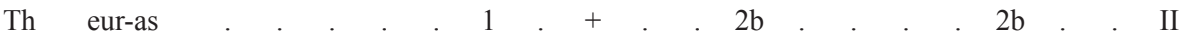

Th eur-med . + . . . + . . . . . . . . . + . I

Th submed . . 1 . . . . . . . . . . . . . . . I

Th eur-as . . . . . . . . . . . . . I

Th eur-med . . . . + . . . . . . . . . I

\begin{tabular}{|c|c|c|c|c|c|c|c|c|c|c|c|c|c|c|c|c|c|c|}
\hline $\begin{array}{c}\text { pont-med } \\
\text { eur-as }\end{array}$ & + & $\begin{array}{l}+ \\
.\end{array}$ & $\begin{array}{c}+ \\
2 \mathrm{~m}\end{array}$ & $\begin{array}{l}1 \\
1\end{array}$ & $\begin{array}{l}+ \\
3\end{array}$ & + & $\begin{array}{l}1 \\
+\end{array}$ & $\begin{array}{l}+ \\
+\end{array}$ & $\begin{array}{l}+ \\
+\end{array}$ & + & . & 3 & + & $\begin{array}{l}+ \\
+\end{array}$ & $\begin{array}{c}+ \\
2 \mathrm{a}\end{array}$ & $\begin{array}{l}1 \\
1\end{array}$ & $\begin{array}{l}+ \\
1\end{array}$ & 1 \\
\hline subboreal & + & 1 & + & . & . & 1 & + & + & 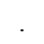 & . & + & 1 & 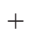 & + & + & + & 1 & 1 \\
\hline submed & . & + & . & . & $2 a$ & 1 & 1 & $2 b$ & + & . & . & + & + & + & 1 & . & + & + \\
\hline pont & . & $2 b$ & $2 b$ & . & $2 a$ & 4 & $2 b$ & $2 \mathrm{a}$ & + & . & . & 1 & $\cdot$ & $2 \mathrm{a}$ & . & . & 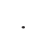 & \\
\hline eur-sib & + & . & . & + & . & + & $\cdot$ & + & . & + & + & $\mathrm{r}$ & $\cdot$ & . & + & . & + & \\
\hline eur & + & $\mathrm{r}$ & . & . & . & 1 & + & . & . & . & + & ${ }^{\circ}$ & $\mathrm{r}$ & . & 1 & . & + & . \\
\hline pont & . & + & . & . & . & + & + & . & + & . & . & $\cdot$ & $\mathrm{r}$ & 4 & $2 \mathrm{a}$ & . & + & + \\
\hline pont-med & . & $2 b$ & . & . & $\mathrm{r}$ & . & . & . & 4 & . & . & r & $\cdot$ & $\mathrm{r}$ & $2 \mathrm{a}$ & . & . & 3 \\
\hline eur-as & . & . & $2 \mathrm{a}$ & . & . & . & . & + & + & . & . & r & . & - & & + & + & + \\
\hline
\end{tabular}


Number of relevé

$\begin{array}{llllllllllllllllll}1 & 2 & 3 & 4 & 5 & 6 & 7 & 8 & 9 & 10 & 11 & 12 & 13 & 14 & 15 & 16 & 17 & 18\end{array}$

Dichantium ishaemum

Teucrium polium

Achillea crithmifolia

Hieracium praealtum

Trifolium scabrum

Convolvulus cantabrica

Centaurea rhenana

Asperula cynanchica

Hypericum perforatum

Euphrasia stricta

Linaria genistifolia

Hieracium hoppeanum

Dasypyrum villosum

Helianthemum nummularium

Carthamus lanatus

Stipa capillata

Achillea nobilis

Allium flavum

Teucrium chamaedrys

Astragalus onobrychis

Other species

Anthemis ruthenica

Plantago lanceolata

Crepis setosa

Scleranthus perennis

Bromus squarrosus

Lotus angustissimus

Galium tenuissimum

Stachys angustifolia

Potentilla inclinata

Ceratodon purpureus

Ornithogalum umbellatum

Potentilla argentea

Cichorium intybus

Syntrichia ruralis

Brachythecium albicans

Bombycilaena erecta

Hypochaeris radicata

Erodium cicutarium

Echium vulgare

Herniaria hirsuta

Jasione heldreichii

Vicia grandiflora

Cynodon dactylon

Filago vulgaris

Hypericum rumeliacum

Euphorbia myrsinites

Xeranthemum annuum

Aegilops triuncialis

$\begin{array}{cc}\mathrm{H} & \text { med-as } \\ \mathrm{H} & \text { pont-med } \\ \mathrm{H} & \text { pann-bal } \\ \mathrm{H} & \\ \mathrm{Th} & \text { med-as } \\ \mathrm{H} & \text { pont } \\ \mathrm{H} & \text { submed } \\ \mathrm{H} & \text { eur-med } \\ \mathrm{H} & \text { cosm } \\ \mathrm{Th} & \text { eur-med } \\ \mathrm{H} & \text { pont-sib } \\ \mathrm{H} & \text { eur-med } \\ \mathrm{H} & \text { submed } \\ \mathrm{Ch} & \text { alp-med } \\ \mathrm{Th} & \text { submed } \\ \mathrm{H} & \text { pont-med } \\ \mathrm{H} & \text { eur-as } \\ \mathrm{K} & \text { med } \\ \mathrm{H} & \text { submed } \\ \mathrm{H} & \text { eur-as }\end{array}$

$.5+1+.3+.2 \mathrm{a}$

\begin{tabular}{|c|c|c|c|c|c|c|c|c|c|c|c|c|c|c|c|c|c|c|}
\hline submed & + & + & . & . & + & $\mathrm{r}$ & 3 & - & - & + & + & . & . & 1 & $\mathrm{r}$ & + & + & . \\
\hline $\operatorname{cosm}$ & + & + & 1 & 1 & . & + & 1 & + & . & $2 \mathrm{a}$ & $2 \mathrm{a}$ & . & $\cdot$ & . & $\cdot$ & + & + & . \\
\hline eur-med & . & + & + & + & 1 & + & $\cdot$ & . & + & $\cdot$ & 1 & $\cdot$ & . & . & + & $\mathrm{r}$ & . & . \\
\hline eur-med & 3 & + & . & . & 1 & . & + & . & . & • & . & . & + & + & + & . & + & . \\
\hline submed & . & + & . & . & 1 & + & + & . & . & . & $2 \mathrm{~m}$ & . & . & . & . & $\mathrm{r}$ & + & . \\
\hline med & . & + & + & + & . & . & . & . & + & . & $\cdot$ & . & + & + & $\mathrm{r}$ & . & . & . \\
\hline pont-as & . & . & + & + & . & . & . & 1 & + & . & . & . & . & . & + & . & . & . \\
\hline pont-med & + & $\mathrm{r}$ & . & . & . & . & . & . & . & . & . & . & . & + & + & . & . & + \\
\hline eur-as & . & + & + & + & . & . & $\mathrm{r}$ & . & . & . & . & . & . & . & . & . & + & . \\
\hline cosm;temp & + & . & 1 & + & + & . & . & . & . & . & . & + & . & . & 1 & . & . & 1 \\
\hline pont-submed & . & + & + & . & . & . & . & . & + & . & . & . & . & + & + & . & . & + \\
\hline pont & . & . & . & . & . & + & + & . & . & . & + & . & + & + & . & . & + & . \\
\hline eur-sib & + & . & + & + & . & $\mathrm{r}$ & . & . & + & + & . & . & . & . & . & . & . & . \\
\hline cosm;temp & 1 & . & 1 & . & . & + & . & . & . & . & . & + & . & . & 1 & . & . & . \\
\hline subboreal & . & $2 \mathrm{a}$ & . & . & . & . & 1 & . & . & . & . & . & $2 \mathrm{a}$ & $2 \mathrm{a}$ & . & . & $2 \mathrm{a}$ & . \\
\hline eur-med & . & . & . & . & + & . & . & . & . & + & + & $\mathrm{r}$ & . & . & . & + & . & . \\
\hline eur-med & . & . & + & + & . & $\mathrm{r}$ & . & . & . & . & . & . & $\mathrm{r}$ & . & . & . & $\mathrm{r}$ & . \\
\hline subboreal & + & . & . & . & . & . & . & . & . & 1 & 1 & . & . & . & . & + & . & . \\
\hline eur-as & . & . & . & . & + & . & . & . & $\mathrm{r}$ & . & $\mathrm{r}$ & + & . & . & . & + & . & . \\
\hline eur-as & . & . & . & . & . & . & . & + & + & + & + & . & . & . & . & + & . & . \\
\hline eur-med & . & . & . & . & . & . & $\mathrm{r}$ & . & . & . & . & . & $\mathrm{r}$ & + & . & . & + & . \\
\hline submed & . & . & . & . & . & . & . & + & + & . & $\mathrm{r}$ & . & . & . & . & + & . & . \\
\hline $\operatorname{cosm}$ & + & . & . & + & . & . & . & . & . & 1 & + & . & . & . & . & + & . & . \\
\hline eur-as & . & . & . & + & . & . & . & . & + & + & . & . & . & . & + & . & . & . \\
\hline bal & . & . & . & . & . & . & . & + & . & . & . & + & . & . & . & . & . & + \\
\hline submed & . & . & . & . & $\mathrm{r}$ & . & . & . & . & . & . & + & . & . & . & . & . & . \\
\hline submed & . & . & . & . & + & . & . & . & . & . & . & + & . & . & $\cdot$ & . & . & . \\
\hline eur-as & . & . & . & . & . & . & . & + & . & . & . & . & . & . & . & . & . & . \\
\hline
\end{tabular}


Number of relevé

$\begin{array}{llllllllllllllllll}1 & 2 & 3 & 4 & 5 & 6 & 7 & 8 & 9 & 10 & 11 & 12 & 13 & 14 & 15 & 16 & 17 & 18\end{array}$

\begin{tabular}{|c|c|c|c|c|c|c|c|c|c|c|c|c|c|c|c|c|c|c|c|c|c|}
\hline Ziziphora capitata & $\mathrm{Th}$ & med & $\cdot$ & $\theta^{\prime}$ & $\cdot$ & $\cdot$ & & & $\cdot$ & + & · & 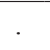 & $\cdot$ & $\cdot$ & . & ${ }^{\circ}$ & $\cdot$ & $\cdot$ & $\cdot$ & & 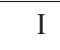 \\
\hline Velezia rigida & Th & submed & & . & $\cdot$ & . & . & . & . & + & ${ }^{\circ}$ & 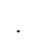 & . & . & . & . & . & . & & & 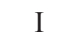 \\
\hline Plantago subulata & $\mathrm{H}$ & med & . & + & . & . & 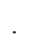 & . & . & 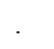 & . & . & . & . & . & + & 1 & . & 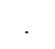 & & \\
\hline Veronica arvensis & $\mathrm{Th}$ & eur-sib & . & . & . & . & . & . & . & . & + & . & + & . & . & . & . & + & . & . & I \\
\hline Trifolium retusum & $\mathrm{Th}$ & med & 1 & . & . & . & . & . & . & . & . & + & . & . & . & . & . & + & . & . & \\
\hline Leontodon crispus & $\mathrm{H}$ & pont-med & . & . & . & . & . & $\mathrm{r}$ & . & . & . & . & . & . & . & $\mathrm{r}$ & . & . & . & + & I \\
\hline Centaurium erythraea & $\mathrm{H}$ & submed & . & + & . & . & . & . & . & . & . & . & . & . & $\mathrm{r}$ & . & . & . & . & . & 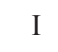 \\
\hline Verbascum adrianopolitanum & $\mathrm{H}$ & bal & . & . & . & . & . & . & $\mathrm{r}$ & . & . & . & . & . & . & $\mathrm{r}$ & . & . & . & . & I \\
\hline Dianthus pinifolius & $\mathrm{H}$ & bal-dac & . & . & . & . & . & . & + & . & . & . & . & . & . & + & . & . & . & + & 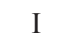 \\
\hline Sedum acre & $\mathrm{H}$ & eur-med & . & . & . & . & . & . & . & . & . & . & . & + & . & . & . & . & . & . & I \\
\hline Achillea coarctata & $\mathrm{H}$ & pont-med & . & . & . & . & + & . & . & . & . & . & . & + & . & . & . & . & . & . & 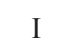 \\
\hline Dactylis glomerata & $\mathrm{H}$ & eur-as & . & . & . & $2 \mathrm{a}$ & . & . & . & . & + & . & . & . & . & . & . & . & . & + & 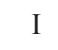 \\
\hline Agrostis canina & $\mathrm{H}$ & eur-sib & . & . & . & . & . & . & $\mathrm{r}$ & . & . & . & . & . & 4 & . & . & . & . & + & 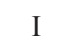 \\
\hline Cynosurus echinatus & $\mathrm{H}$ & submed & . & . & . & + & . & . & . & . & + & . & . & . & . & . & . & . & . & . & I \\
\hline Viola arvensis & Th & eur & . & . & . & + & . & . & . & . & + & . & . & . & . & . & . & . & . & . & I \\
\hline Bromus tectorum & $\mathrm{Th}$ & boreal & . & . & . & . & . & . & . & . & . & . & $2 \mathrm{~m}$ & . & . & . & . & + & . & . & I \\
\hline Hypericum thasium & $\mathrm{H}$ & bal & . & . & . & . & . & . & . & . & . & . & . & . & . & . & $\mathrm{r}$ & . & . & . & I \\
\hline Dianthus armeria & Th & eur & . & . & 1 & . & . & . & . & . & . & . & . & . & . & . & . & . & . & . & I \\
\hline Alyssum desertorum & Th & eur-med & . & . & . & . & . & . & . & . & . & . & 1 & . & . & . & . & + & . & . & I \\
\hline Rorippa thracica & $\mathrm{H}$ & submed & . & . & . & + & . & + & . & . & . & . & . & . & . & . & . & . & . & . & 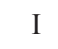 \\
\hline Sideritis montana & Th & submed & . & . & . & . & . & . & . & + & . & . & + & . & . & . & . & . & . & . & I \\
\hline Potentilla neglecta & $\mathrm{H}$ & subboreal & . & . & . & . & . & . & . & + & . & . & . & . & . & . & . & . & . & + & I \\
\hline Echinops ritro & $\mathrm{H}$ & eur-sib & . & . & . & . & . & . & . & . & . & . & $\mathrm{r}$ & . & . & . & . & + & . & . & I \\
\hline Centaurea diffusa & $\mathrm{H}$ & pont-med & . & . & . & . & . & . & . & + & + & . & . & . & . & . & . & . & . & . & I \\
\hline Anthoxanthum odora & $\mathrm{H}$ & eur-as & . & . & . & . & . & . & . & . & . & . & . & . & $2 \mathrm{~b}$ & + & . & . & . & . & I \\
\hline Gypsophila muralis & $\mathrm{H}$ & eur-as & . & . & 1 & . & . & . & . & . & . & . & . & . & . & . & + & . & . & . & I \\
\hline Trifolium diffusum & $\mathrm{Th}$ & submed & . & . & . & + & . & . & . & . & + & . & . & . & . & . & . & . & . & . & I \\
\hline Orlaya kochii & $\mathrm{Th}$ & eur-as & . & . & . & . & . & . & . & . & + & . & . & . & . & . & . & . & . & . & I \\
\hline Geranium rotundifolium & $\mathrm{Th}$ & eur-as & . & . & . & . & . & . & . & . & . & . & + & . & . & . & . & + & . & . & I \\
\hline Verbascum thapsiforme & $\mathrm{H}$ & submed & . & . & . & . & . & . & . & . & . & . & . & . & . & . & . & + & $2 \mathrm{a}$ & . & . \\
\hline Koeleria macrantha & $\mathrm{H}$ & eur & . & . & . & . & + & . & . & . & . & . & . & 3 & . & . & . & . & . & . & I \\
\hline Orlaya grandiflora & Th & ap-bal & . & $\mathrm{r}$ & . & . & . & . & . & . & . & . & . & . & . & . & . & $\mathrm{r}$ & . & . & I \\
\hline Filipendula vulgaris & $\mathrm{H}$ & eur-med & . & . & . & . & . & . & . & . & $\mathrm{r}$ & . & . & . & . & . & . & . & . & . & I \\
\hline Chamomilla recutita & $\mathrm{Th}$ & eur-as & . & . & . & . & . & . & . & . & . & + & . & . & . & . & . & . & . & . & I \\
\hline Dorycnium herbaceum & $\mathrm{H}$ & eur-med & . & . & . & . & . & . & . & + & . & . & . & . & . & . & . & . & . & . & I \\
\hline Reseda lutea & $\mathrm{H}$ & subboreal & . & . & . & . & . & . & . & . & . & . & . & . & . & . & . & + & . & . & I \\
\hline Dianthus moesiacus & $\mathrm{H}$ & bal & . & . & . & . & . & . & . & . & + & . & . & . & . & . & . & . & . & . & I \\
\hline Trifolium setiferum & Th & med & . & . & . & . & . & . & . & . & + & . & . & . & . & . & . & . & . & . & I \\
\hline Phleum phleoides & $\mathrm{H}$ & eur-as & . & . & . & . & . & . & . & . & . & . & . & . & . & . & . & . & . & $\mathrm{r}$ & I \\
\hline Erysimum repandum & Th & eur-as & . & . & . & . & . & . & . & + & . & . & . & . & . & . & . & . & . & . & I \\
\hline Sherardia arvensis & $\mathrm{Th}$ & med & . & . & . & . & . & . & . & . & + & . & . & . & . & . & . & . & . & . & I \\
\hline Astragalus hamosus & $\mathrm{H}$ & eur-as & . & . & . & . & . & . & . & + & . & . & . & . & . & . & . & . & . & . & I \\
\hline Trifolium incarnatum & $\mathrm{Th}$ & submed & . & . & . & . & . & . & . & . & + & . & . & . & . & . & . & . & . & . & I \\
\hline Carduus nutans & $\mathrm{H}$ & eur-med & . & . & . & . & . & . & . & . & . & + & . & . & . & . & . & . & . & . & I \\
\hline Medicago lupulina & $\mathrm{Th}$ & eur-as & . & $\cdot$ & . & $\cdot$ & . & + & . & . & . & . & . & . & . & . & . & . & . & 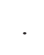 & 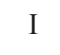 \\
\hline Allium vineale & $\mathrm{K}$ & eur-NAm & . & . & . & . & . & . & . & . & . & . & . & + & . & . & . & . & . & . & 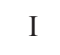 \\
\hline Convolvulus arvensis & $\mathrm{H}$ & $\operatorname{cosm}$ & + & . & . & . & . & . & . & . & . & . & . & . & . & . & . & . & . & . & \\
\hline Trifolium repens & $\mathrm{H}$ & eur-sib & . & . & + & . & . & . & . & . & . & . & . & . & . & . & . & . & . & . & \\
\hline Tragopogon dubius & $\mathrm{H}$ & eur-med & . & & . & . & $\cdot$ & + & & . & . & . & . & . & . & . & . & . & . & & \\
\hline
\end{tabular}


Number of relevé

\begin{tabular}{|c|c|c|c|c|c|c|c|c|c|c|c|c|c|c|c|c|c|c|c|c|c|}
\hline Marrubium peregrinum & $\mathrm{H}$ & submed & . & . & . & . & . & . & . & . & . & . & $\mathrm{r}$ & . & r & . & . & . & . & . & I \\
\hline Muscari sp. & $\mathrm{K}$ & & . & . & . & . & . & . & . & . & . & . & . & . & . & . & . & . & . & + & I \\
\hline Lotus corniculatus & $\mathrm{H}$ & eur-med & . & . & . & . & . & + & . & . & . & . & . & . & . & . & . & . & . & . & I \\
\hline Dianthus pallens & $\mathrm{H}$ & bal-dac & . & . & . & . & . & . & . & . & + & . & . & . & . & . & . & . & . & . & I \\
\hline Bromus arvensis & $\mathrm{Th}$ & eur-as & . & . & . & . & . & . & . & + & . & . & . & . & . & . & . & . & . & . & I \\
\hline Chenopodium botrys & Th & boreal & . & . & . & . & . & . & . & . & . & $2 \mathrm{a}$ & . & . & . & . & . & . & . & . & I \\
\hline Ferulago sylvatica & $\mathrm{H}$ & submed & . & . & . & . & . & . & . & . & . & . & . & . & . & . & . & . & . & 1 & I \\
\hline Racomitrium canescens & $\mathrm{H}$ & boreal & . & . & . & . & . & . & . & . & . & . & . & . & . & . & + & . & . & . & I \\
\hline Verbascum floccosum & $\mathrm{H}$ & submed & . & . & . & . & . & . & . & + & . & . & . & . & . & . & . & . & . & . & I \\
\hline Trifolium purpureum & $\mathrm{Th}$ & med & . & . & $\mathrm{r}$ & . & . & . & . & . & . & . & . & . & . & . & . & . & . & . & I \\
\hline Centaurea cyanus & $\mathrm{Th}$ & eur-med & . & . & . & . & . & . & . & . & . & . & . & . & . & . & . & $\mathrm{r}$ & . & . & I \\
\hline Lathyrus nissolia & Th & eur-med & . & . & . & . & . & . & . & + & . & . & . & . & . & . & . & . & . & . & I \\
\hline Scabiosa triniifolia & $\mathrm{Th}$ & bal & . & . & . & . & . & . & . & . & . & . & . & . & . & . & . & . & . & 1 & I \\
\hline Valerianella coronata & $\mathrm{Th}$ & eur-med & . & . & . & . & . & . & . & . & . & . & . & . & . & . & . & $\mathrm{r}$ & . & . & I \\
\hline Ornithopus compressus & Th & submed & . & . & . & . & . & . & . & . & . & . & . & . & . & + & . & . & . & . & I \\
\hline Trifolium echinatum & Th & med & . & . & . & . & . & . & . & + & . & . & . & . & . & . & . & . & . & . & I \\
\hline Pterygoneurum ovatum & $\mathrm{H}$ & temp & . & . & . & . & . & . & . & + & . & . & . & . & . & . & . & . & . & . & I \\
\hline Euphorbia chamaesyce & $\mathrm{Th}$ & eur-as & . & . & . & . & . & . & . & . & . & $2 \mathrm{a}$ & . & . & . & . & . & . & . & . & I \\
\hline Salvia argentea & $\mathrm{H}$ & med & . & . & . & . & . & . & . & . & . & . & $\mathrm{r}$ & . & . & . & . & . & . & . & I \\
\hline Bryum caespiticium & $\mathrm{H}$ & temp & . & . & . & . & . & . & . & . & . & . & . & . & . & . & . & . & . & 1 & I \\
\hline Barbula unguiculata & $\mathrm{H}$ & & . & . & . & . & . & . & . & + & . & . & . & . & . & . & . & . & . & . & I \\
\hline Xeranthemum cylindraceum & $\mathrm{Th}$ & submed & . & . & . & . & . & . & . & + & . & . & . & . & . & . & . & . & . & . & I \\
\hline Poa angustifolia & $\mathrm{H}$ & $\operatorname{cosm}$ & . & . & . & . & . & . & . & . & . & . & . & . & $\mathrm{r}$ & . & . & . & . & . & I \\
\hline Coronilla scorpioides & Th & submed & . & . & . & . & . & . & . & + & . & . & . & . & . & . & . & . & . & . & I \\
\hline Anthemis tinctoria & $\mathrm{H}$ & eur-sib & + & . & . & . & . & . & . & . & . & . & . & . & . & . & . & . & . & . & I \\
\hline Alyssum hirsutum & $\mathrm{Th}$ & submed & . & . & . & . & . & . & 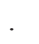 & + & . & . & . & . & . & . & . & . & . & . & I \\
\hline Crucianella angustifolia & Th & med & . & . & . & . & . & . & . & 1 & . & . & . & . & . & . & . & . & . & . & I \\
\hline Melica ciliata & $\mathrm{H}$ & eur-submed & . & . & . & . & . & . & . & . & . & . & . & . & . & . & . & . & . & + & I \\
\hline $\begin{array}{l}\text { Viscaria vulgaris ssp. } \\
\text { atropurpurea }\end{array}$ & $\mathrm{H}$ & eur-sib & $\cdot$ & $\cdot$ & . & . & . & . & . & . & . & . & . & . & . & . & + & . & . & . & I \\
\hline
\end{tabular}

Localities: 1.-E of the Tvarditzha town, $42.67839^{\circ} \mathrm{N}, 25.95018^{\circ} \mathrm{E}, 10.06 .2005 ;$ 2.-North slopes of Sredna Gora mountains, $\mathrm{S}$ of the Tvarditzha town, $42.64797^{\circ} \mathrm{N}, 25.92345^{\circ} \mathrm{E}, 14.06 .2005$; 3.-Svetiilijski vazvishenia hill, N of Sokol village, $42.41123^{\circ} \mathrm{N}$, 26.10004 ${ }^{\circ} \mathrm{E}, 11.06 .2005$; 4.- $\mathrm{E}$ of Zlatari village, $42.3847^{\circ} \mathrm{N}, 26.2315^{\circ} \mathrm{E}, 29.06 .2004 ; 5 .-\mathrm{W}$ of Nautchen village, $42.56536^{\circ} \mathrm{N}$,

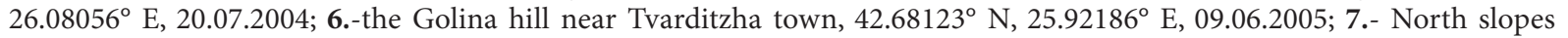
of Sredna Gora mountains, S of Tvarditzha town, $42.65615^{\circ} \mathrm{N}, 25.92084^{\circ} \mathrm{E}, 14.06 .2005$; 8.-NW of Peshtersko village, $42.75153^{\circ} \mathrm{N}, 27.33362^{\circ} \mathrm{E}, 22.07 .2005 ;$ 9.-E of Zlatari village, $42.38478^{\circ} \mathrm{N}, 26.23153^{\circ} \mathrm{E}, 29.06 .2004$; 10.-E of the Sliven town, $42.6686^{\circ} \mathrm{N}, 26.4010^{\circ} \mathrm{E}, 25.07 .2004 ;$ 11.-S of Kozharevo village, $42.68975^{\circ} \mathrm{N}, 25.87724^{\circ} \mathrm{E}, 06.06 .2005 ; 12 .-\mathrm{W}$ of Nautchen village, $42.5653^{\circ} \mathrm{N}, 26.0805^{\circ} \mathrm{E}, 20.07 .2004 ; 13$.-North slopes of Sredna Gora mountains, $\mathrm{S}$ of the Tvarditzha town, $42.64839^{\circ} \mathrm{N}$, $25.92273^{\circ} \mathrm{E}, 14.06 .2005 ; 14 .-$ Sredna Gora mountains, near the Zhrebtchevo dam, $42.60160^{\circ} \mathrm{N}, 25.91573^{\circ} \mathrm{E}, 14.06 .2005 ; 15 .-\mathrm{E}$ of Banja village, $42.61227^{\circ} \mathrm{N}, 26.00080^{\circ} \mathrm{E}, 10.06 .2005$; 16.-S of Kozharevo village, $42.68935^{\circ} \mathrm{N}, 25.87649^{\circ} \mathrm{E}, 06.06 .2005$; 17.-near the Zhrebtchevo dam, $42.63688^{\circ} \mathrm{N}, 25.89264^{\circ} \mathrm{E}, 14.06 .2005$; 18.-the Marashka Mogila hill, $\mathrm{N}$ of mezhda village, $42.36735^{\circ} \mathrm{N}, 26.25332^{\circ} \mathrm{E}, 29.06 .2004$. 
Table 2: Ecological characteristics of the sampled relevés.

Tabela 2: Ekološke značilnosti vzorčenih popisov.

\begin{tabular}{cccccccc}
\hline relevé & $\begin{array}{c}\text { slope } \\
{\left[{ }^{\circ}\right]}\end{array}$ & soil depth & soil moisture & $\mathbf{p H}$ & $\begin{array}{c}\mathbf{E C} \\
{\left[\boldsymbol{\mu S} . \mathbf{c m}^{-1}\right]}\end{array}$ & $\begin{array}{c}\text { humus } \\
{[\mathbf{\%}]}\end{array}$ & $\begin{array}{c}\mathbf{C a C O}_{3} \\
{\left[\mathbf{m g}^{\mathbf{1}} \mathbf{~ I}^{-1}\right]}\end{array}$ \\
\hline 1 & 0 & medium & dry & 6,12 & 24 & 7.98 & 78 \\
2 & $5-10$ & medium & dry & 6,2 & 30 & 3,7 & 35 \\
3 & $1-5$ & medium & dry & 5,95 & 29 & 2,13 & 36 \\
4 & $10-15$ & medium & dry & - & - & - & - \\
5 & $5-10$ & shallow & dry & - & - & - & - \\
6 & $10-15$ & medium & dry & 6,45 & 63 & 13,88 & 96 \\
7 & $1-5$ & shallow & dry & - & - & - & - \\
8 & $10-15$ & shallow & dry & - & - & - & - \\
9 & $1-5$ & medium & dry & 7,06 & 79 & 1,79 & 96 \\
10 & 0 & shallow & dry & - & - & - & - \\
11 & 0 & shallow & dry & - & - & - & - \\
12 & $1-5$ & shallow & dry & - & - & - & - \\
13 & $5-10$ & medium & moderatly moist & 6,41 & 23 & 3,1 & 33 \\
14 & $10-15$ & shallow & dry & 6,03 & 22 & 2,33 & 32 \\
15 & $10-15$ & shallow & dry & 6,41 & 40 & 3,46 & 43 \\
16 & 0 & shallow & dry & - & - & - & - \\
17 & $1-5$ & medium & dry & 6,11 & 20 & 3,4 & 28 \\
18 & $10-15$ & shallow & dry & 5,44 & 43 & 1,04 & 36 \\
\hline
\end{tabular}

